\title{
KAJIAN KELAYAKAN EKONOMI RENCANA PEMBANGUNAN INSTALASI PENGOLAHAN AIR LIMBAH (IPAL) DOMESTIK KOMUNAL SISTEM UASB-DHS DI KOTA BOGOR
}

\section{Study of Economic Feasibility on the Development Plan of Domestic Wastewater Treatment Communal System UASB-DHS in Bogor}

\author{
Rudi Nugroho dan Agus Rifai \\ Pusat Teknologi Lingkungan \\ Badan Pengkajian dan Penerapan Teknologi (BPPT), \\ Jalan M.H. Thamrin No. 8 Jakarta 10340 \\ Email : rudi_nugroho@hotmail.com
}

Diterima: 5 Juni 2012; Direvisi: 12 Juni 2012; Disetujui: 20 Juni 2012

\begin{abstract}
Domestic wastewater is one of the potential sources of environment pollution. Based on the JICA Report, 1995 the environmental pollution in Jabodetabek was $80 \%$ caused by the domestic wastewater. To minimize the environmental pollution, the wastewater have to be treated before discharge to river. Problem which often emerge in management of domestic waste is the limited land area and existing fund to built a wastewater treatment facility and also the high operating cost. To overcome these problems, it needs development of low cost wastewater treatment technology with high removal efficiency, easy to operate and also should be compact. A combination technology of Upflow Anaerobic Sludge Blanket (UASB) and Downflow Hanging Sponge (DHS) represents an economic wastewater treatment, easy to operate and has high removal efficiency that is $98 \%$ for $B O D$ and $99,8 \%$ for bacterium. However, to build the wastewater treatment facility by using the UASB and DHS technology, it needs a feasibility study. This paper explains an economic and social feasibility study of application the UASB and DHS wastewater treatment technology at Bogor City. $B y$ the calculation of benefit and cost ratio $(B C R)$, the result shows that the $B C R$ is 2.13. It means the UASB and DHS wastewater treatment project at Bogor City was feasible.
\end{abstract}

Keywords: domestic wastewater, upflow anaerobik sludge blanket, social economic study.

\begin{abstract}
Abstrak
Air limbah rumah tangga merupakan salah satu potensi sumber pencemaran lingkungan . Berdasarkan Laporan JICA , 1995 pencemaran lingkungan di Jabodetabek adalah 80 \% disebabkan oleh air limbah rumah tangga. Untuk meminimalkan pencemaran lingkungan, air limbah harus diperlakukan sebelum dibuang ke sungai . Masalah yang sering muncul dalam pengelolaan limbah domestik adalah luas lahan terbatas dan dana yang ada untuk membangun fasilitas pengolahan air limbah dan juga biaya operasional yang tinggi . Untuk mengatasi masalah tersebut, perlu pengembangan biaya rendah teknologi pengolahan air limbah dengan efisiensi penyisihan yang tinggi , mudah dioperasikan dan juga harus kompak. Sebuah teknologi kombinasi Upflow Anaerobic Sludge Blanket ( UASB ) dan aliran bawah Hanging Sponge ( DHS ) merupakan pengolahan air limbah ekonomi , mudah dioperasikan dan memiliki efisiensi penyisihan tinggi yaitu $98 \%$ untuk BOD dan 99,8 \% untuk bakteri . Namun, untuk membangun fasilitas pengolahan air limbah dengan menggunakan UASB dan teknologi DHS, perlu studi kelayakan . Makalah ini menjelaskan studi kelayakan ekonomi dan sosial dari penerapan teknologi pengolahan air limbah UASB dan DHS di Kota Bogor . Dengan perhitungan manfaat dan rasio biaya ( BCR ), hasilnya menunjukkan bahwa BCR 2.13 . Ini berarti proyek pengolahan air limbah UASB dan DHS di Kota Bogor adalah layak.
\end{abstract}

Kata kunci : air limbah rumah tangga , anaerobik selimut lumpur, studi sosial ekonom 


\section{PENDAHULUAN}

Kecamatan Bogor Utara merupakan bagian dari Kota Bogor dengan luas administratif 1772 $\mathrm{Ha}$. Sebagai wilayah perkotaan yang berlokasi dekat dengan Ibukota Negara, mempunyai potensi yang strategis bagi perkembangan dan pertumbuhan ekonomi dan jasa, pusat kegiatan nasional untuk industri, perdagangan, transportasi, komunikasi, dan pariwisata. Oleh karena itu, wajar jika tingkat pertumbuhan penduduk akhir -akhir ini menunjukkan kemajuan yang signifikan.

Sistem sanitasi yang digunakan di wilayah Kecamatan Bogor Utara saat ini menggunakan sistem on-site (sistem pembuangan setempat) yaitu dengan menggunakan septik tank dan sumur resapan untuk limbah tinja[1]. Sedangkan limbah cair yang berasal dari kegiatan dapur, kamar mandi, WC langsung dialirkan ke sistem drainase lalu ke badan air penerima. Kepadatan penduduk yang tinggi juga berpengaruh terhadap ketersediaan lahan penempatan septik tank dan sumur resapan. Meskipun septik tank sudah dilengkapi sumur resapan, tidak tertutup kemungkinan adanya air rembesan effluen tangki septik yang akan mencemari air tanah disekitarnya dan apabila air tanah tersebut dimanfaatkan masyarakat maka dapat menyebabkan timbulnya penyakit. Berdasarkan analisis lingkungan strategis Kota Bogor terdapat lima isu-isu yang mendapat prioritas penaggulangan, salah satunya yaitu kebersihan kota dan lingkungan hidup. Sebagai salah satu upaya penanganan masalah kebersihan kota dan lingkungan hidup, maka perlu dipertimbangkan adanya sistem penanganan air limbah domestik yang meliputi sistem penyaluran dan pengolahan terpusat. Sistem penyaluran berupa sistem perpipaan sedangkan untuk sistem pengolahan terpusat dipilih suatu teknologi pengolahan air limbah domestik yang efektif dan efisien dalam rangka memperbaiki sistem kualitas sanitasi lingkungan eksisting. Diutamakan pula bahwa teknologi tersebut mengedepankan suatu produk yang dapat didaur ulang, dalam hal ini adalah produk limbah yang secara kualitas dapat digunakan kembali untuk berbagai keperluan. Teknologi tersebut yaitu Upflow Anaerobik Sludge Blanket (UASB) dan Downflow Hanging Sponge (DHS)[2].

Teknologi UASB adalah teknologi pengolahan air limbah secara biologi anaerobik. Keuntungan menggunakan teknologi ini diantaranya adalah biaya operasional murah ditunjang dapat menghasilkan gas metan yang dapat dimanfaatkan sebagai bahan bakar. Sedangkan teknologi DHS adalah teknologi sistem biologi aerobik menggunakan susunan sponge yang digantung dan berada dalam suatu tangki atau bak terbuka. Dalam sistem DHS ini, air limbah akan mengalir turun melewati permukaan sponge yang ditumbuhi lapisan film mikroba. Dengan demikian akan terjadi proses degradasi polutan dalam air limbah oleh mikroba yang berada di permukaan sponge secara aerobik. Flow diagram proses pengolahan air limbah dengan kombinasi UASB DHS diperlihatkan pada gambar 1 .

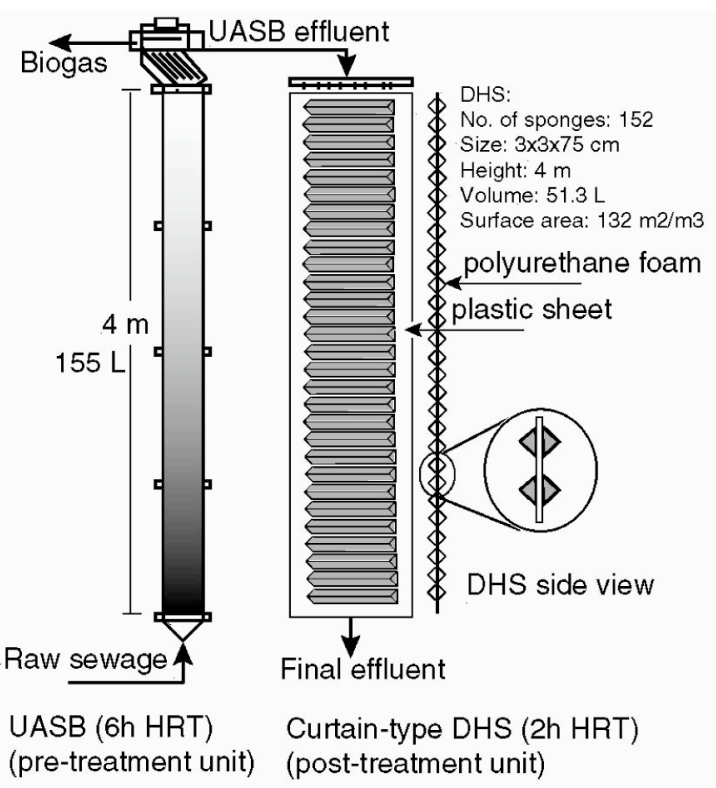

Gambar 1. Flow proses pengolahan air limbah sistem UASB-DHS[2].

Untukmeyakinkansistem pengolahan air limbah domestik terpusat dengan UASB dan DHS tersebut layak atau tidak dibangun maka perlu dilakukan analisis sosial ekonomi kelayakan yang menyoroti segala macam aspek yang diperkirakan memiliki relevansi kuat dengan rencana pembangunan.

\section{BAHAN DAN METODE}

\subsection{Identifikasi Masalah}

Kepadatan pendudukyang tinggi menyebabkan tidak tersedia lahan yang cukup untuk membangun septik tankdan area peresapan. Bidang peresapan yang tidak terlalu luas dan didukung sifat tanah dengan permeabilitas rendah mempunyai potensi kemungkinan terjadi pencemaran air bersih oleh air limbah melalui kebocoran-kebocoran pipa. Disisi lain, sistem sanitasi setempat (on site) dapat menimbulkan permasalahan berkaitan dengan aspek-aspek penanganan air limbah. Oleh karena itu untuk mengatasi dampak yang akan timbul maka perlu adanya perubahan penanganan air limbah dari on-site sistem menjadi off-site sistem. Penanganan air limbah dengan sistem perpipaan dan unit pengolahan kombinasi UASB dan DHS merupakan cara yang dapat diterapkan karena unit ini tidak memerlukan lahan yang luas, ramah 
lingkungan dan mudah dalam pengoperasiannya.

\subsection{Metodologi Kajian}

Metodologi yang digunakan dalam kajian sosial ekonomi ini adalah kegiatan diawali dengan kajian pustaka yang dilakukan untuk mengetahui kondisi wilayah penelitian. Setelah itu dilanjutkan dengan Survei lokasi ke permukiman penduduk di kota bogor untuk mengetahui secara langsung persepsi masyarakat kota terhadap rencana pembangunan IPAL domestik komunal.

Selain itu juga dilakukan survei ke beberapa sentra bisnis produk samping dari adanya IPAL seperti ke tempat penjualan pupuk, penjualan tanaman hias dan lain sebagainya. Analisis manfaat ekonomi dilakukan dengan perhitungan Benefit Cost Ratio (BCR) yakni perbandingan nilai keuntungan dan biaya untuk masa sekarang. Bila BCR > 1 maka proyek dinyatakan layak.

\section{HASIL DAN PEMBAHASAN}

\subsection{Jumlah dan Kepadatan Penduduk}

Kepadatan penduduk di Kecamatan Bogor Utara tidak merata karena dipengaruhi oleh penyebaran fasilitas-fasilitas pelayanan yang lain. Jumlah penduduk Kecamatan Bogor Utara pada tahun 2003 sebanyak 144.590jiwa[3]. Berdasarkan data bahwa Kelurahan Bantarjati dan Kelurahan Tegalgundil mempunyai jumlah penduduk yang paling tinggi akan tetapi mempunyai luas wilayah yang sempit yaitu cuma 1,7 km2 dan 1,98 km2. Banyaknya jumlah penduduk merupakan salah satu akibat adanya aktivitas pembangunan perumahan danfasilitas-fasilitas kotayang semakin tinggi dibandingkan dengan kelurahan lainnya.

\subsection{Tingkat Pendidikan Penduduk}

Pendidikan merupakan salah satu aspek penting yang berfungsi meningkatkan kualitas hidup masyarakat. Semakin tinggi tingkat pendidikan masyarakat, menunjukan kualitas sumber daya manusia yang semakin baik. Tingkat pendidikan masyarakat Kecamatan Bogor Utara sebagian mencapai perguruan tinggi.

\subsection{Jenis Mata Pencaharian Penduduk}

Mata pencaharian masyarakat di kecamatan Bogor Utara bervariasi akan tetapi sebagian besar usaha dalam bidang jasa. Hal ini erat kaitannya dengan Kota Bogor sebagai pusat kegiatan -kegiatan Internasional konfrensi-konfrensi antara lain seperti Informal Meeting untuk APEC yang dihadiri oleh para pemimpin negara dari Asia Pacifik termasuk Amerika Serikat.

\subsection{Sarana Air Bersih}

Sistem penyediaan air bersih penduduk Kecamatan Bogor Utara terdiri dari sistem perpipaan dan nonperpipaan. Berdasarkan data dari Bidang P3KI Dinas Kesehatan Kota Bogor tahun 2004, tingkat pelayanan sistem perpipaan sudah mencapai $47,53 \%$. Sistem pelayanan perpipaan terbesar di wilayah Kelurahan Bantarjati dan Tegalgundil. Sedangkan sistem nonperpipaan yang terdiri dari sumur pompa tangan (SPT), sumur gali (SGL) dan sanyo banyak terdapat di Kelurahan Kedunghalang, Ciparigi dan Ciluar. Oleh karena itu resiko terhadap pencemaran sarana air bersih cukup rentan mengingat masih banyak sumber air bersih yang berasal dari nonperpipaan.

\subsection{Sistem Sanitasi}

Sistem pengelolaan limbah manusia (limbah tinja) yang digunakan oleh penduduk Kecamatan Bogor Utara adalah sistem pembuangan setempat (on site). Sedangkan air buangan yang berasal dari kamar mandi, dapur dan tempat cuci ada yang disalurkan ke saluran -saluran drainase yang menuju badan sungai. Akan tetapi secara keseluruhan masyarakat sudah memiliki sarana sanitasi pribadi.

\subsection{Drainase}

Kondisi sistem drainase di sekitar wilayah Kecamatan Bogor Utara secara umum merupakan sistem drainase alam. Sistem drainase yang ada dibedakan sebagai berikut : - Sistem drainase di wilayah permukiman. Saluran-saluran alam hampir menyebar disetiap kelurahan yang ada. Hal ini berfungsi sebagai saluran pengumpul dari saluran drainase yang ada disekeliling area permukiman. Seperti halnya KelurahanBantarjati,TegalgundildanCiparigidilalui Sungai Ciparigi, Kelurahan Cibuluh, Tanahbaru dan Ciluar dilalui Sungai Ciluar dan Kelurahan Cimahpar dilalui Sungai Cimahpar sedangkan Kelurahan Kedunghalang dilalui Sungai Ciliwung. - Sistem drainase di luar wilayah permukiman. Wilayah Kecamatan Bogor Utara dilalui oleh sungai besar yaitu Sungai Ciliwung yang mengalir sampai ke Jakarta. Sungai ini merupakan badan air yang menerima buangan akhir dari anakan -anakan sungai yang mengalir dari Wilayah Bogor Utara dan sebagian Kota Bogor lainnya.

\subsection{Kelayakan Ekonomi}

Aspek ini lebih cenderung kepada pemikiran masyarakat, proyek tersebut akan berguna/ bermanfaat terhadap masyarakat atau tidak. Definisi dari manfaat suatu proyek adalah kegunaan dan atau keuntungan setelah proyek tersebut selesai dibangun. Atau hasil produksi dari suatu proyek yang biasa dijual atau dinikmati[4].

Manfaat yang diperoleh dengan dibangunnya 
Instalasi Pengolahan Air Limbah (IPAL) UASB dan DHS ini dapat dibedakan sebagai berikut : Manfaat langsung adalah manfaat yang langsung diperoleh dari suatu proyek[5]. Manfaat langsung dari pembangunan IPAL UASB dan DHS ini adalah :

- Penurunan BOD secara signifikan pada air sungai. Hal ini telah dibuktikan pada IPAL Sewon Bantul Yogyakarta yaitu keberadaan IPAL dapat menurunkan BOD air sungai dari $332 \mathrm{mg} / \mathrm{l}$ menjadi $30 \mathrm{mg} / \mathrm{l}$ sehingga estetika lingkungan disekitar daerah aliran sungai akan tetap terjaga termasuk pula penurunan pencemaran air tanah dapat diminimalisir[6]. - SebagaiproduksampingdarilnstalasiPengolahan Air Limbah adalah berupa lumpur organik yang dihasilkan pada unit pengolahan air limbah yaitu UASB dan DHS. Lumpur sebagai produk samping dari instalasi pengolahan air limbah domestik, kaya akan bahan-bahan organik yang dapat membantu proses pertumbuhan tanaman menjadi lebih baik.

Proses pengelolaan lumpur organik sebagai produk samping dari IPAL menjadi pupuk organik telah dilakukan oleh IPAL Bojongsoang Bandung. Melalui proses pengeringan dan pengayakan lumpur tersebut menjadi bahan kering yang penggunaannya cukup dicampur dengan media tanah sehingga menjadi media tanam yang baik, khususnya untuk media tanam tanaman hias. Proses pengolahanlumpur yang diterapkan di IPAL Bojongsoang Bandung dapat dijelaskan pada gambar 2 sebagai berikut:

Komposisi lumpur kering hasil pengolahan limbah Instalasi Pengolahan Bojongsoang dapat dilihat pada lampiran Tabel 1.

Pada proyek percontohan IPAL semarang[6] dengan kapasitas 326.000 jiwa setiap hari menghasilkan 65 m3/hari lumpur maka jika IPAL UASB dan DHS kapasitas pengolahan 15.000 jiwa setiap hari dapat menghasilkan $3 \mathrm{~m} 3 /$ hari lumpur. Jika berat jenis lumpur 1,03 kg//tr atau 1030 kg/m3 maka produksi lumpur 3090 kg/ hari. Sehingga jumlah lumpur yang dihasilakan selama satu tahun yaitu $1.127 .850 \mathrm{~kg} / \mathrm{tahun}$.

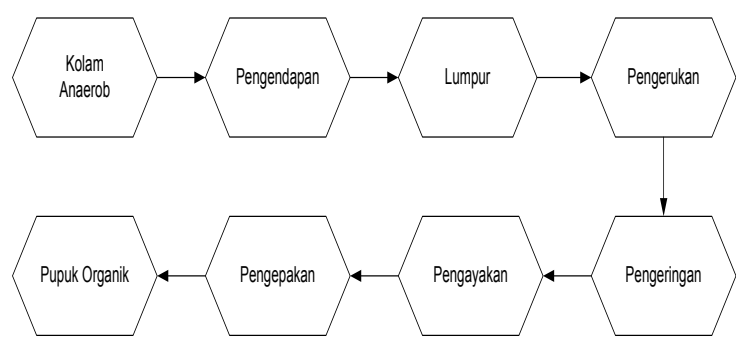

Gambar 2. Proses Pengolahan Lumpur IPAL Bojongsoang [6].

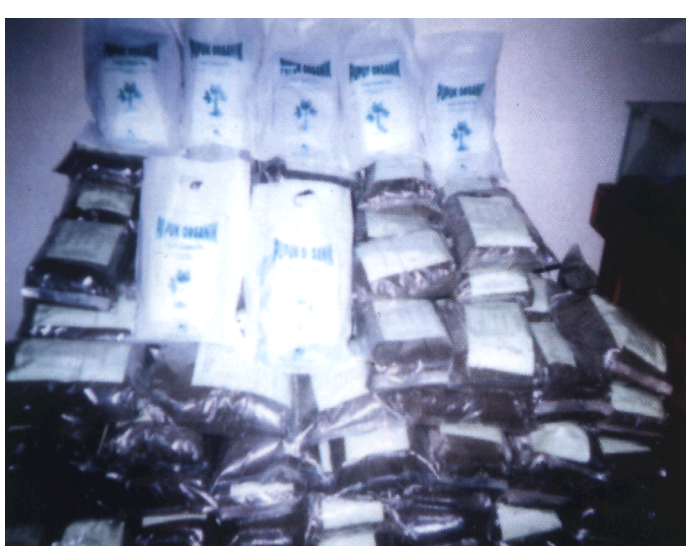

Gambar 3. Pupuk Organik Hasil Pengolahan

Berdasarkan hasil survai harga pupuk humus/organik dipasaran Rp.10.000,00 per kemasan seberat $25 \mathrm{~kg}$. Maka nilai manfaat dari pengolahan lumpur menjadi pupuk adalah sebesar Rp.451.140.000,00 setiap tahun.

Sebagai salah satu pemanfaatan produk dari Instalasi Pengolahan Air Limbah yaitu pupuk organik selain dijual dapat juga dimanfaatkan untuk pembibitan tanaman baik tanaman hias maupun tanaman keras. Jenis tanaman yang bisa dikembangkan adalah sebagai berikut :

Tanaman keras meliputi Palm jantan dan glodokan. Palm jantan dan glodokan merupakan jenis tanaman yang sering digunakan sebagai penghijauan. Oleh karena itu jenis tanaman ini mempunyai nilai jual yang cukup tinggi. Harga palm jantan dan glodokan umur enam bulan dipasaran masing-masing $60.000,00$ dan $10.000,00$ per batang. Berdasarkan survai lapangan bahwa rumah pembibitan tanaman keras dengan ukuran 5 × $10 \mathrm{~m}$ dapat menampung tanaman sebanyak 150 tanaman maka besarnya manfaat adalah sebagai berikut:(Data Primer, 2006) Tanaman palm jantan :

$100 \times(12 / 6) \times$ Rp.60.000,00 = Rp.12.000.000,00 per tahun Tanaman glodokan :

$50 \times(12 / 6) \times$ Rp. $10.000,00=$ Rp. $1.000 .000,00$ per tahun

Tanaman hias, berbagai macam tanaman hias dapat dikembangkan yaitu lamtana, lavender, erepah, cemara perak, mawar, kaktus, variasoto, portulata, beuty taiwan dan lain lain. Jenis tanaman hias ini mempunyai nilai jual biasanya umur tiga bulan seharga 3000,00 per tanaman Berdasarkan survai lapangan bahwa rumah pembibitan tanaman hias dengan ukuran $5 \times 10$ m dapat menampung tanaman sebanyak 300 tanaman maka besarnya manfaat adalah $300 \times(12 / 3)$ x Rp.3000,00 = Rp. 3.600.000,00 per tahun. (Data Primer, 2006). 
Tabel 1. Komposisi Lumpur Kering

\begin{tabular}{llccc}
\hline No. & Komposisi & Simbol & Hasil Analisa & Satuan \\
\hline 1 & Carbon & $\mathrm{C}$ & 11,78 & $\%$ \\
2 & Nitrogen & $\mathrm{N}$ & 1,24 & $\%$ \\
3 & Phospor & $\mathrm{P}$ & 1,63 & $\mathrm{Mg} / 100 \mathrm{gr}$ \\
4 & Kalium & $\mathrm{K}$ & 48,5 & $\mathrm{Mg} / 100 \mathrm{gr}$ \\
5 & Calsium & $\mathrm{C}$ & 38,96 & $\mathrm{Me} / 100 \mathrm{gr}$ \\
6 & Magnesium & $\mathrm{Mg}$ & 4,90 & $\mathrm{Me} / 100 \mathrm{gr}$ \\
7 & Natrium & $\mathrm{Na}$ & 2,04 & $\mathrm{Me} / 100 \mathrm{gr}$ \\
8 & Boron & $\mathrm{Bo}$ & 2,40 & $\mathrm{Mg} / \mathrm{kg}$ \\
9 & Aluminium & $\mathrm{Al}$ & 312 & $\mathrm{Mg} / \mathrm{kg}$ \\
10 & Sulfur & $\mathrm{S}$ & 928 & $\mathrm{Mg} / \mathrm{kg}$ \\
11 & Seng & $\mathrm{Zn}$ & 127,8 & $\mathrm{Mg} / \mathrm{kg}$ \\
12 & Tembaga & $\mathrm{Cu}$ & 0,7 & $\mathrm{Mg} / \mathrm{kg}$ \\
13 & Mangan & $\mathrm{Mn}$ & 301 & $\mathrm{Mg} / \mathrm{kg}$ \\
14 & besi & $\mathrm{Fe}$ & 402 & $\mathrm{Mg} / \mathrm{kg}$ \\
\hline
\end{tabular}

Tabel 2. Manfaat Ekonomi Proyek IPAL UASB dan DHS (dalam rupiah)

\begin{tabular}{cccccc}
\hline Tahun & 'upuk Organik & $\begin{array}{c}\text { Pembibitan } \\
\text { Tanaman }\end{array}$ & Biogas & Sedot WC & Total Manfaat \\
\cline { 2 - 6 } 2007 & $451,140,000.00$ & $16,600,000.00$ & $1,283,659,375.00$ & $180,000,000.00$ & $1,931,399,375.00$ \\
2008 & $473,697,000.00$ & $17,430,000.00$ & $1,347,842,343.75$ & $189,000,000.00$ & $2,027,969,343.75$ \\
2009 & $497,381,850.00$ & $18,301,500.00$ & $1,415,234,460.94$ & $198,450,000.00$ & $2,129,367,810.94$ \\
2010 & $522,250,942.50$ & $19,216,575.00$ & $1,485,996,183.98$ & $208,372,500.00$ & $2,235,836,201.48$ \\
2011 & $548,363,489.63$ & $20,177,403.75$ & $1,560,295,993.18$ & $218,791,125.00$ & $2,347,628,011.56$ \\
2012 & $575,781,664.11$ & $21,186,273.94$ & $1,638,310,792.84$ & $229,730,681.25$ & $2,465,009,412.14$ \\
2013 & $604,570,747.31$ & $22,245,587.63$ & $1,720,226,332.48$ & $241,217,215.31$ & $2,588,259,882.74$ \\
2014 & $634,799,284.68$ & $23,357,867.02$ & $1,806,237,649.11$ & $253,278,076.08$ & $2,717,672,876.88$ \\
2015 & $666,539,248.91$ & $24,525,760.37$ & $1,896,549,531.56$ & $265,941,979.88$ & $2,853,556,520.72$ \\
2016 & $699,866,211.36$ & $25,752,048.39$ & $1,991,377,008.14$ & $279,239,078.88$ & $2,996,234,346.76$ \\
2017 & $734,859,521.92$ & $27,039,650.80$ & $2,090,945,858.55$ & $293,201,032.82$ & $3,146,046,064.10$ \\
2018 & $771,602,498.02$ & $28,391,633.34$ & $2,195,493,151.48$ & $307,861,084.46$ & $3,303,348,367.30$ \\
2019 & $810,182,622.92$ & $29,811,215.01$ & $2,305,267,809.05$ & $323,254,138.68$ & $3,468,515,785.67$ \\
2020 & $850,691,754.07$ & $31,301,775.76$ & $2,420,531,199.50$ & $339,416,845.62$ & $3,641,941,574.95$ \\
2021 & $893,226,341.77$ & $32,866,864.55$ & $2,541,557,759.48$ & $356,387,687.90$ & $3,824,038,653.70$ \\
2022 & $937,887,658.86$ & $34,510,207.78$ & $2,668,635,647.45$ & $374,207,072.29$ & $4,015,240,586.39$ \\
2023 & $984,782,041.80$ & $36,235,718.17$ & $2,802,067,429.83$ & $392,917,425.91$ & $4,216,002,615.70$ \\
2024 & $1,034,021,143.89$ & $38,047,504.08$ & $2,942,170,801.32$ & $412,563,297.20$ & $4,426,802,746.49$ \\
2025 & $1,085,722,201.09$ & $39,949,879.28$ & $3,089,279,341.38$ & $433,191,462.06$ & $4,648,142,883.81$ \\
2026 & $1,140,008,311.14$ & $41,947,373.24$ & $3,243,743,308.45$ & $454,851,035.17$ & $4,880,550,028.00$ \\
2027 & $1,197,008,726.70$ & $44,044,741.91$ & $3,405,930,473.87$ & $477,593,586.93$ & $5,124,577,529.40$ \\
\hline
\end{tabular}

Sumber : Hasil Analisa dan Perhitungan 
Tabel 3. Perbandingan Manfaat dan Biaya Proyek yang di diskontowaktu sekarang (dalam rupiah)

\begin{tabular}{|c|c|c|c|c|c|c|c|}
\hline Tahun & Investasi & O\&M & Total C & Manfaat & Dis Fact $12 \%$ & PV Gr C & PV Gr M \\
\hline 2006 & $8,172,426,400.00$ & & $8,172,426,400.00$ & & 1.0000 & $8,172,426,400.00$ & 0.00 \\
\hline 2007 & & $127,200,000$ & $127,200,000.00$ & $1,931,399,375.00$ & 0.8929 & $113,576,880.00$ & $1,724,546,501.94$ \\
\hline 2008 & & $134,460,000$ & $134,460,000.00$ & $2,027,969,343.75$ & 0.7972 & $107,191,512.00$ & $1,616,697,160.84$ \\
\hline 2009 & & $142,173,000$ & $142,173,000.00$ & $2,129,367,810.94$ & 0.7118 & $101,198,741.40$ & $1,515,684,007.83$ \\
\hline 2010 & & $150,370,650$ & $150,370,650.00$ & $2,235,836,201.48$ & 0.6355 & $95,560,548.08$ & $1,420,873,906.04$ \\
\hline 2011 & & $159,087,083$ & $159,087,082.50$ & $2,347,628,011.56$ & 0.5674 & $90,266,010.61$ & $1,332,044,133.76$ \\
\hline 2012 & & $168,359,127$ & $168,359,126.63$ & $2,465,009,412.14$ & 0.5006 & $84,280,578.79$ & $1,233,983,711.72$ \\
\hline 2013 & & $178,226,542$ & $178,226,541.96$ & $2,588,259,882.74$ & 0.4523 & $80,611,864.93$ & $1,170,669,944.96$ \\
\hline 2014 & & $188,732,274$ & $188,732,273.95$ & $2,717,672,876.88$ & 0.4039 & $76,228,965.45$ & $1,097,668,074.97$ \\
\hline 2015 & & $199,922,733$ & $199,922,733.04$ & $2,853,556,520.72$ & 0.3606 & $72,092,137.53$ & $1,028,992,481.37$ \\
\hline 2016 & & $211,848,100$ & $211,848,099.62$ & $2,996,234,346.76$ & 0.322 & $68,215,088.08$ & $964,787,459.66$ \\
\hline 2017 & & $224,562,658$ & $224,562,657.53$ & $3,146,046,064.10$ & 0.2875 & $64,561,764.04$ & $904,488,243.43$ \\
\hline 2018 & & $238,125,159$ & $238,125,158.62$ & $3,303,348,367.30$ & 0.2567 & $61,126,728.22$ & $847,969,525.89$ \\
\hline 2019 & & $252,599,222$ & $252,599,221.58$ & $3,468,515,785.67$ & 0.2292 & $57,895,741.59$ & $794,983,818.08$ \\
\hline 2020 & & $268,053,768$ & $268,053,768.20$ & $3,641,941,574.95$ & 0.2046 & $54,843,800.97$ & $745,141,246.24$ \\
\hline 2021 & & $284,563,501$ & $284,563,500.70$ & $3,824,038,653.70$ & 0.1827 & $51,989,751.58$ & $698,651,862.03$ \\
\hline 2022 & & $302,209,424$ & $302,209,424.24$ & $4,015,240,586.39$ & 0.1631 & $49,290,357.09$ & $654,885,739.64$ \\
\hline 2023 & & $321,079,419$ & $321,079,418.81$ & $4,216,002,615.70$ & 0.1456 & $46,749,163.38$ & $613,849,980.85$ \\
\hline 2024 & & $341,268,865$ & $341,268,865.43$ & $4,426,802,746.49$ & 0.13 & $44,364,952.51$ & $575,484,357.04$ \\
\hline 2025 & & $362,881,332$ & $362,881,331.96$ & $4,648,142,883.81$ & 0.1161 & $42,130,522.64$ & $539,649,388.81$ \\
\hline 2026 & & $386,029,324$ & $386,029,324.14$ & $4,880,550,028.00$ & 0.1037 & $40,031,240.91$ & $506,113,037.90$ \\
\hline 2027 & & $410,835,108$ & $410,835,108.49$ & $5,124,577,529.40$ & 0.0926 & $38,043,331.05$ & $474,535,879.22$ \\
\hline & & & & & & $9,612,676,080.84$ & $20,461,700,462.21$ \\
\hline
\end{tabular}

Pemanfaatan biogas dari reaktor UASB sebagai bahan bakar rumah tangga. Pada IPAL Tahu Lamper Tengah dengan debit $130 \mathrm{~m} 3 / \mathrm{hari}$ menghasilkan biogas 106,42 m3/hari (Baristandag, 2005), sehingga untuk IPAL dengan debit 2000 $\mathrm{m} 3 /$ hari dapat menghasilkan biogas $1655 \mathrm{~m} 3 /$ hari. Berdasarkan survai lapangan harga biogas setengah dari harga bahan bakar gas (BBG). Jika keperluan dan harga BBG Rp. 4.250,00/m3/hari maka untuk biogas Rp. 2.125,00/m3/hari jadi nilai manfaat dari biogas selama satu tahun adalah $1655 \times 365 \times$ Rp.2.125,00 = 1.283.659.375,00.

Masyarakat tidak perlu melakukan pengurasan septik tank karena kotoran dari WC akan masuk ke pipa saluran air limbah dan selanjutnya disalurkan ke unit pengolahan. Jika biaya pengurasan per m3 sebesar 60.000,00 (menurut perusahaan jasa sedot WC yaitu Doremon) maka manfaat IPAL bisa menghilangkan biaya pengurasan tersebut sebesar 120.000,00 setiap dua tahun dengan asumsi volume septik tank $2 \mathrm{~m} 3$ dan pengurasan dilakukan dua tahun sekali maka nilai manfaat setiap dua tahun adalah $3000 \times$ Rp.120.000,00 $=$ Rp.360.000.000,00. Jadi nilai manfaat setiap tahunnya sebesar Rp.180.000.000,00.

Manfaat tidak langsung adalah manfaat yang baru dapat dirasakan setelah beberapa waktu dari proyek tersebut selesai dibangun. Manfaat tidak langsung dari pembangunan IPAL UASB dan DHS ini antara lain adalah : Air hasil olahan IPAL UASB dan DHS dapat dimanfaatkan masyarakat untuk kebutuhan pertanian dan perikanan, sehingga dapat juga menciptakan lapangan kerja informal bagi penduduk yang tinggal disekitar lokasi IPAL UASB dan DHS. Hal ini seperti yang dilakukan oleh masyarakat yang tinggal disekitar lokasi IPAL Bojongsoang Bandung[6].

Menciptakan lapangan kerja dan peluang berusaha pada fase pelaksanaan dan pasca pembangunan IPAL UASB dan DHS. Misal pada fase pembangunan bisa menyerap tenaga kerja lokal seperti pekerjaan pembersihan lokasi, galian tanah dan lain-lain. Sedangkan pada fase pasca pembangunan dengan diadakannya pelatihan pembibitan tanaman, pembuatan pupuk organik. Manfaat Nyata (Tangible Benefit) Manfaat nyata adalah manfaat yang dapat 
diukur dalam bentuk suatu nilai uang. Contoh manfaat nyata dengan dibangunnya IPAL UASB dan DHS ini adalah pendapatan penduduk di sekitar lokasi IPAL UASB dan DHS bertambah karena hasil dari perikanan, pertanian dan adanya penyerapan tenaga kerja untuk pembibitan tanaman dan pengolahan pupuk organik.

Manfaat tidak nyata adalah manfaat dari suatu proyek yang tidak dapat diukur, tetapi dapat dirasakan dan diyakini ada manfatnya[4] . Contoh dari manfaat tidak nyata ini adalah : Keberadaan IPAL UASB dan DHS ini sangat membantu pemerintah Kota Bogor dalam usaha meningkatkan kualitas lingkungan permukiman pada wilayah perkotaan. Hal ini disebabkan air limbah domestik tidak langsung dibuang ke sungai sehingga estetika lingkungan baik disekitar permukiman maupun disekitar daerah aliran sungai akan tetap terjaga termasuk pula penurunan pencemaran air tanah dapat diminimalisir.

Adanya alih teknologi dimana unit DHS merupakan sistem pengolahan baru secara aerobik yang ditemukan oleh Prof. Harada dari Jepang. Dari beberapa jenis manfaat proyek diatas dapat dilihat bahwa IPAL UASB dan DHS dapat memberikan manfaat baik yang dapat dinilai secara nominal ataupun tidak. Menurut Kadariah dkk bahwa proyek memberikan dan menghasilkan pengembalian sosial atau social return terhadap pemerintah dan masyarakat. Untuk riil tolok ukur aspek sosial ini sangat sulit karena bersifat intangible sehingga nilainya tidak dapat dikonversikan ke suatu nilai uang[8].

Umumnya sudut pandang rekayasa dan kajian aspek sosial ini memberikan hasil yang berupa kecenderungan[9]. Yang bisa dilihat adalah bahwa dengan adanya suatu proyek pada suatu daerah maka akan menaikkan pendapatan masyarakat setempat, rasakeamananyang lebih besardan rasa kenyamanan. Untuk beberapa manfaat langsung yang dapat dinilai dengan uang dapat dilihat pada lampiran tabel 2. Pada tabel ini nilai manfaat dari tahun ke tahun di asumsikan meningkat $5 \%$.

Manfaat langsung ini dinilai dapat menaikkan tingkat perekonomian masyarakat yang tinggal dilokasi sekitar IPAL.

$$
\begin{aligned}
B C R= & \frac{\begin{array}{l}
\text { Nilaisekarang } \\
\text { benefit }
\end{array}}{\text { Nilaisekarang }}=\frac{(P V) B}{(P V) C} \\
\text { biaya } & \frac{20.461 .700 .462,21}{9.612 .676 .080,84} \\
= & 2.13
\end{aligned}
$$

Asumsi nilai manfaat mengalami kenaikan setiap tahun sebesar $5 \%$ yang ekuivalen dengan kenaikan biaya operasional dan pemeliharaan
IPAL UASB dan DHS. Sedangkan perbandingan nilai manfaat dan biaya proyek yang digunakan untuk menghitung nilai benefit cost rasio (BCR) dapat dilihat pada lampiran Tabel 3.

Dari hasil perhitungan diatas menunjukkan bahwaproyeklayakditerimaataudilaksanakan.Jadi dari sisi sosial ekonomi, pembangunan IPAL UASB dan DHS dengan metode benefit cost rasio layak untuk dilaksanakan karenanilai BCR >1 yakni 2,13.

\section{KESIMPULAN}

Dari hasil analisis kelayakan, penerapan Instalasi Pengolahan Air Limbah Domestik Komunal di Kota Bogor akan membawa manfaat yang signifikan terhadap masyarakat maupun terhadap lingkungan. Berdasarkan hasil analisis ekonomi sosial untuk menilai kelayakan penerapan Instalasi Pengolahan Air Limbah Domestik UASB dan DHS di Wilayah Kecamatan Bogor Utara, maka dapat diambil kesimpulan bahwa rencana pembangunan Instalasi Pengolahan Air Limbah Domestik UASB dan DHS ini layak untuk direalisasikan dengan alasan nilai benefit cost rasio> 1 yaitu sebesar 2,13.

\section{DAFTAR PUSTAKA}

1. Agus R dan R. Nugroho. 2007 "Kajian Pendahuluan Kelayakan Penerapan Instalasi Pengolahan Air Limbah Domestik Secara Komunal di Permukiman Kota Bogor".di JurnalAir Indonesia Volume3Nomor2.

2. Izarul M, A. Ohasi, dan H. Harada. 2000." Combination of UASB Reactor and A Curtain Type DHS Reactor as Cost-effective Sewage Treatment System for Developing Countries". Water Science and Technology. Vol 42. No.S 3-4. IWA Publishing.

3. Kantor Statistisk Kota Bogor.2005. KotaBogor Dalam Angka.

4. Bachrawi, Sanusi.2000. Pengantar Evaluasi Proyek. Fakultas Ekonomi Universitas Indonesia.Jakarta

5. Kodoatie, Robert J.2001.Analisis Ekonomi Teknik.Andi.Yogyakarta

6. Anonim. 2003. Laporan Final Identifikasi Kegiatan Pengembangan Sarana Air Limbah Metro Semarang. Departemen Permukiman dan Pengembangan Wilayah Direktorat Jendral Pengembangan Perkotaan. Semarang.

7. Letinga $G$ et.al.2002.Solid Removalin Upflow Anaerobik Reactor. Review Paper Bioresources Technology. Belanda

8. Kadariah.1986. Evaluasi Proyek Analisa Ekonomi Edisi Satu. Lembaga Penerbit Fakultas Ekonomi Universitas Indonesia.Jakarta

9. Gray, Clive dkk. 2002.Pengantar Evaluasi Proyek Edisi Kedua. PT. Gramedia Pustaka Utama. Jakarta.

10. Letinga $G$ et.al.2002.Solid Removalin Upflow Anaerobik Reactor. Review Paper Bioresources Technology. Belanda.

11. Kadariah.1986. Evaluasi Proyek Analisa Ekonomi Edisi Satu. Lembaga Penerbit Fakultas Ekonomi Universitas Indonesia.Jakarta 12. Gray, Clive dkk. 2002.Pengantar Evaluasi Proyek Edisi Kedua. PT. Gramedia Pustaka Utama. Jakarta. 
